\title{
Investigating Hydrogen Isotope Variation during Heating of n-Alkanes under Limited Oxygen Conditions: Implications for Palaeoclimate Reconstruction in Archaeological Settings
}

\author{
Rory Connolly ${ }^{1,2}$, Margarita Jambrina-Enríquez ${ }^{1,3}$, Antonio V. Herrera-Herrera ${ }^{1}$ (D) and Carolina Mallol ${ }^{1,2,4, *(D)}$ \\ 1 Instituto Universitario de Bio-Organica Antonio Gonzalez (IUBO), Universidad de La Laguna, \\ 38206 Canary Islands, Spain; rconnoll@ull.es (R.C.); mjambrin@ull.edu.es (M.J.-E.); \\ avherrer@ull.edu.es (A.V.H.-H.) \\ 2 Departmento de Geografia e Historia, Universidad de La Laguna, 38200 Canary Islands, Spain \\ 3 Departamento de Biología Animal, Edafología y Geología, Facultad de Ciencias, Universidad de La Laguna, \\ 38200 Canary Islands, Spain \\ 4 Interdisciplinary Center for Archaeology and the Evolution of Human Behaviour (ICArEHB), \\ Universidade do Algarve, Campus de Gambelas, Edificio 1, 8005-139 Faro, Portugal \\ * Correspondence: cmallol@ull.edu.es
}

Citation: Connolly, R.; Jambrina-Enríquez, M.; Herrera-Herrera, A.V.; Mallol, C. Investigating Hydrogen Isotope Variation during Heating of n-Alkanes under Limited Oxygen Conditions: Implications for Palaeoclimate Reconstruction in Archaeological Settings. Molecules 2021, 26, 1830. https://doi.org/ $10.3390 /$ molecules 26071830

Academic Editor: James Barker

Received: 22 February 2021

Accepted: 21 March 2021

Published: 24 March 2021

Publisher's Note: MDPI stays neutral with regard to jurisdictional claims in published maps and institutional affiliations.

Copyright: (c) 2021 by the authors. Licensee MDPI, Basel, Switzerland. This article is an open access article distributed under the terms and conditions of the Creative Commons Attribution (CC BY) license (https:// creativecommons.org/licenses/by/ $4.0 /)$.
Abstract: This paper reports on a series of heating experiments that focus on $n$-alkanes extracted from leaf, bark, and xylem tissues of the Celtis australis plant. These lipid biomarkers were analysed for their compound-specific hydrogen isotopic composition $\left(\delta^{2} \mathrm{H}_{\mathrm{wax}}\right)$ under limited oxygen conditions at $150,250,350$, and $450^{\circ} \mathrm{C}$. Our results reveal isotopic variations in wax lipids of different plant organs during short-term low-temperature combustion. We conclude that, in the absence of a detailed characterisation of the depositional environment in advance of sampling, $\delta^{2} \mathrm{H}_{\mathrm{wax}}$ values in archaeological or otherwise highly anthropogenic environments should be interpreted cautiously. In addition, we observed that variation in $\delta^{2} \mathrm{H}_{\text {wax }}$ of leaves is minimal at temperatures $\leq 350{ }^{\circ} \mathrm{C}$, highlighting the potential for $\delta^{2} \mathrm{H}_{\mathrm{wax}}$ in thermally altered combustion substrates to yield palaeoclimate information, which could allow researchers to investigate links between archaeological and climatic records at a high spatial and temporal resolution.

Keywords: $n$-alkanes; compound-specific isotope analysis; hydrogen isotopes; palaeoclimate; archaeology; thermal alteration; combustion

\section{Introduction}

Compound-specific hydrogen isotope analysis of $n$-alkanes $\left(\delta^{2} \mathrm{H}_{\mathrm{wax}}\right)$ derived from terrestrial and aquatic plant waxes has been shown to record plant source water's isotopic composition and has thus emerged as a robust proxy for palaeohydrological reconstruction [1-4]. Numerous studies have reported on the wide range of environmental factors which govern hydrogen isotopic fractionation in plant waxes, which include precipitation $\delta^{2} \mathrm{H}$, precipitation amount, plant type, plant physiology, temperature, aridity, seasonality, and humidity [5-8]. However, it is notable that despite the recent upsurge in the application of this proxy in archaeological settings, little attention has been afforded to the potential impacts of human activities on $\delta^{2} \mathrm{H}_{\text {wax }}$. Anthropogenic combustion features and their associated residues, which are chronologically and geographically ubiquitous in archaeological contexts, particularly stand out as an important source of potential bias and the effects of short-term low temperature $\left(<450{ }^{\circ} \mathrm{C}\right)$ combustion on $\delta^{2} \mathrm{H}_{\text {wax }}$ values are not well understood.

Anthropogenic combustion features, or hearths, have been the focus of a considerable body of archaeological research in recent years using an array of high-resolution analytical techniques [9-13]. The processes involved in forming anthropogenic combustion features 
are complex and subject to a considerable range of culturally and environmentally mediated variables. However, at the most basic level, these features are composed of a thermally altered substrate overlain by a black combustion layer resulting from the deliberate exploitation and management of fire by one or more humans in the past. Experimental studies suggest that the substrate on which the fire is lit (i.e., occupation surface) do not typically exceed temperatures of $300^{\circ} \mathrm{C}$ and may provide preferential conditions for the preservation of lipid biomarkers $[14,15]$. The most rudimentary form of anthropogenic combustion feature is a simple hearth in which combustion is carried out on a horizontal surface. Other common forms include cuvette fires, or pit hearths, in which the combustion is carried out in a bowl-like depression. In some instances, pebbles or flagstones may be placed around the fire in a horizontal or vertical position and act as heat retainers, altering the combustion's archaeological and sedimentary signature [16,17]. Traditionally, palaeoenvironmental information from combustion features has been derived from analyses of the associated charcoal assemblages [18-21] or phytoliths [22-25], both of which are the product of human activities and depend on the preservation of physical plant remains. The application of lipid biomarker analyses, despite being first approached as early as the 1980s [26-28] is still not widely employed for the study of combustion features. In recent years, decreasing costs and improved access to instrumental analyses has led to a modest increase in the number of studies that have sought to exploit lipid biomarkers' potential and their associated compound-specific isotope ratios to investigate both experimentally derived and archaeological datasets. To date, however, most of these studies have focused on questions related to cooking activities and the identification of potential fuel sources [29-33].

Here, we conducted a series of heating experiments to evaluate molecular and isotopic changes to plant-derived wax lipids during short duration combustion events under limited oxygen conditions using leaves, bark and xylem tissues of the Celtis australis plant, commonly known as the European nettle tree or Mediterranean hackberry. This species represents a common fuel source in archaeological settings, particularly in sites dating to the Middle Palaeolithic [14,17], and in such instances is likely to be an important source of organic residues in archaeological combustion features. In addition, fine charred particles produced during the combustion of these fuel sources are likely to be locally dispersed in surrounding sediments. We aimed to assess the degree of preservation of climatic signals in $\delta^{2} \mathrm{H}_{\mathrm{wax}}$ in anthropogenic combustion features and account for potential biases that could arise due to the mixing of microscopic fine charred particles dispersed in sediments throughout the site.

\section{Results}

\subsection{Concentration and Molecular Distribution of $n$-Alkanes}

Alkanes ranging from $\mathrm{nC}_{18}-\mathrm{nC}_{33}$ were detected in the leaf samples, and from $\mathrm{nC}_{16^{-}}$ $\mathrm{nC}_{31}$ in the bark samples and xylem samples. We observed a prevalence of odd-over-even $n$ alkanes, which is the typical distribution pattern observed for higher order terrestrial plant waxes [34]. Total $n$-alkane concentration ( $\mu \mathrm{g} / \mathrm{g}$ dried sample), Carbon Preference Index $\left(\mathrm{CPI}_{25-33}\right)$, which is determined by the ratio of odd over even carbon number molecular chains and can yield information about the biological source and maturity of organic matter [34], and Average Chain Length $\left(\mathrm{ACL}_{25-33}\right)$ [35] have previously been reported elsewhere [36] and are outlined here for comparison in Table 1.

\subsection{Variation in $\delta^{2} H_{w a x}$ of Thermally Unaltered Reference Samples and Heated Samples of Celtis Australis}

Here we measured the hydrogen isotope composition of different plant organs of Celtis australis during short-term combustions $(1 \mathrm{~h})$ at temperatures of 150, 250, 350, and $450{ }^{\circ} \mathrm{C}$ under limited oxygen conditions. This data is presented in Table 2 below. We report only the $\delta^{2} \mathrm{H}_{\mathrm{wax}}$ of $\mathrm{nC}_{27}, \mathrm{nC}_{29}$ and $\mathrm{nC}_{31}$ because these long-chain alkanes are among the most widely utilised terrestrial plant biomarkers. 
Table 1. Quantitative results for total $n$-alkane concentration, Carbon Preference Index (CPI), and Average Chain Length (ACL). Ref indicates unheated reference samples.

\begin{tabular}{|c|c|c|c|c|c|}
\hline \multicolumn{6}{|l|}{ Celtis Leaves } \\
\hline & Ref & $150^{\circ} \mathrm{C}$ & $250^{\circ} \mathrm{C}$ & $350^{\circ} \mathrm{C}$ & $450{ }^{\circ} \mathrm{C}$ \\
\hline Total $n$-alkane $(\mu \mathrm{g} / \mathrm{g})$ & 459 & 484 & 360 & 97.0 & 28.8 \\
\hline $\mathrm{CPI}_{25-33}$ & 2.7 & 3.3 & 5.6 & 4.3 & 1.1 \\
\hline $\mathrm{ACL}_{25-33}$ & 30.3 & 30.4 & 30.5 & 30.1 & 29.7 \\
\hline \multicolumn{6}{|c|}{ Celtis Branch Interior (Xylem) } \\
\hline & Ref & $150^{\circ} \mathrm{C}$ & $250{ }^{\circ} \mathrm{C}$ & $350^{\circ} \mathrm{C}$ & $450{ }^{\circ} \mathrm{C}$ \\
\hline Total $n$-alkane $(\mu \mathrm{g} / \mathrm{g})$ & 0.9 & 0.9 & 1.2 & 1.6 & 0.1 \\
\hline $\mathrm{CPI}_{25-33}$ & 1.3 & 1.3 & 1.3 & 1.5 & - \\
\hline $\mathrm{ACL}_{25-33}$ & 26.9 & 26.9 & 27.1 & 26.0 & 25.0 \\
\hline \multicolumn{6}{|c|}{ Celtis Branch Exterior (Bark) } \\
\hline & Ref & $150^{\circ} \mathrm{C}$ & $250^{\circ} \mathrm{C}$ & $350^{\circ} \mathrm{C}$ & $450^{\circ} \mathrm{C}$ \\
\hline Total $n$-alkane $(\mu \mathrm{g} / \mathrm{g})$ & 18.5 & 4.2 & 3.5 & 8.5 & 0.1 \\
\hline $\mathrm{CPI}_{25-33}$ & 3.1 & 3.4 & 1.6 & 1.1 & - \\
\hline $\mathrm{ACL}_{25-33}$ & 26.5 & 26.9 & 27.9 & 26.6 & - \\
\hline
\end{tabular}

Table 2. Hydrogen isotope values of individual long-chain $n$-alkanes in thermally unaltered reference samples and heated samples of Celtis australis leaf, branch interior (xylem), and exterior (bark). The $\delta^{2} \mathrm{H}_{\text {wax }}$ values are normalised to the Vienna Standard Mean Ocean Water (VSMOW) standard. Values are expressed in per mil (\%o) with one standard deviation. Ref indicates unheated reference samples and * denotes samples where reproducibility was less than $\pm 5.0 \%$ following three replicates.

\begin{tabular}{|c|c|c|c|c|c|c|c|c|c|c|}
\hline \multicolumn{11}{|c|}{ Celtis Leaves } \\
\hline & Ref & $\sigma$ & $150^{\circ} \mathrm{C}$ & $\sigma$ & $250^{\circ} \mathrm{C}$ & $\sigma$ & $350{ }^{\circ} \mathrm{C}$ & $\sigma$ & $450{ }^{\circ} \mathrm{C}$ & $\sigma$ \\
\hline $\mathrm{C}_{27}$ & -106.7 & 1.2 & -94.3 & 4.3 & -122.1 & 3.2 & -120.5 & 2.9 & -73.3 & 2.1 \\
\hline $\mathrm{C}_{29}$ & -130.7 & 1.0 & -132.0 & 1.4 & -133.9 & 3.7 & -134.8 & 0.6 & -99.5 & 1.0 \\
\hline $\mathrm{C}_{31}$ & -128.2 & 0.6 & -131.3 & 0.9 & -132.8 & 3.0 & -135.0 & 1.7 & -87.0 & $6.1 *$ \\
\hline \multicolumn{11}{|c|}{ Celtis Branch Interior (Xylem) } \\
\hline & Ref & $\sigma$ & $150^{\circ} \mathrm{C}$ & $\sigma$ & $250{ }^{\circ} \mathrm{C}$ & $\sigma$ & $350{ }^{\circ} \mathrm{C}$ & $\sigma$ & $450^{\circ} \mathrm{C}$ & $\sigma$ \\
\hline $\mathrm{C}_{27}$ & - & - & -146.8 & 1.8 & -165.4 & 2.7 & - & - & - & - \\
\hline $\mathrm{C}_{29}$ & - & - & -188.2 & 3.5 & -222.7 & 1.3 & - & - & - & - \\
\hline $\mathrm{C}_{31}$ & -193.4 & 1.1 & -273.7 & 2.4 & -241.2 & 2.2 & - & - & - & - \\
\hline \multicolumn{11}{|c|}{ Celtis Branch Exterior (Bark) } \\
\hline & Ref & $\sigma$ & $150^{\circ} \mathrm{C}$ & $\sigma$ & $250^{\circ} \mathrm{C}$ & $\sigma$ & $350^{\circ} \mathrm{C}$ & $\sigma$ & $450^{\circ} \mathrm{C}$ & $\sigma$ \\
\hline $\mathrm{C}_{27}$ & -167.3 & 0.8 & -190.8 & 2.3 & -224.3 & 3.0 & -204.5 & 0.8 & - & - \\
\hline $\mathrm{C}_{29}$ & -158.5 & 4.0 & -167.7 & 1.5 & -237.8 & $5.2 *$ & -207.5 & 4.1 & - & - \\
\hline $\mathrm{C}_{31}$ & -151.4 & 1.3 & -141.2 & 4.2 & -235.2 & 3.3 & -224.5 & 0.9 & - & - \\
\hline
\end{tabular}

The maximum variation in hydrogen isotope composition observed for each of the sample sets was $49 \%$ o $\left(\mathrm{nC}_{27}\right), \sim 80 \%$ o $\left(\mathrm{nC}_{31}\right)$, and $~ 94 \%$ o $\left(\mathrm{nC}_{31}\right)$ for leaves, xylem, and bark, respectively. Based on the $\mathrm{nC}_{31}$ homologue, for which isotopic determinations could be made using unaltered reference samples in all three sample sets, leaves are enriched in ${ }^{2} \mathrm{H}$ $(-128.2 \%$ o by $\sim 65 \%$ relative to xylem $(-193.4 \%$ o ) and $\sim 23 \%$ relative to bark $(-151.4 \%$ o $)$. For $\mathrm{nC}_{29}$ and $\mathrm{nC}_{31}$, the most common homologues targeted for terrestrial palaeoenvironmental reconstruction, $\delta^{2} \mathrm{H}$ values in leaves was generally minimal at temperatures up to $350{ }^{\circ} \mathrm{C}$, with a maximum variation of $\sim 4$ and $\sim 7 \%$, respectively, ranging from -131 to $-135 \%$ and -128 to $-135 \%$. This is followed by an increasing trend in $\delta^{2} \mathrm{H}_{\text {wax }}$ values at $450{ }^{\circ} \mathrm{C}$. This increase likely arises through the interplay of different factors, including kinetic isotope effects and the formation of alkanes from precursor compounds. In xylem 
samples, there is a decreasing trend toward ${ }^{2} \mathrm{H}$ depleted values between 150 and $250{ }^{\circ} \mathrm{C}$ of $\sim 19 \%$ o $\left(\mathrm{nC}_{27}\right)$ and $\sim 35 \%$ o $\left(\mathrm{nC}_{29}\right)$ despite an increase in total $n$-alkane concentration in these samples.

Although reliable $\delta^{2} \mathrm{H}$ values were not obtained for the unaltered xylem samples for $\mathrm{nC}_{27}$ and $\mathrm{nC}_{29}$, making it difficult to meaningfully compare that sample set, a general decreasing trend is observed for $\mathrm{nC}_{31}$ between the reference samples and those heated to $250{ }^{\circ} \mathrm{C}$. It is notable that bark samples followed a similar trend as the leaf samples toward more depleted values at $250^{\circ} \mathrm{C}$, followed by a slight increase in $\delta^{2} \mathrm{H}$ values at $350{ }^{\circ} \mathrm{C}$. Total variation in hydrogen isotope composition of the heated bark samples was in the range of $\sim 57 \%$ o $\left(\mathrm{nC}_{27}\right), \sim 79 \%$ o $\left(\mathrm{nC}_{29}\right)$, and $\sim 94 \%$ o $\left(\mathrm{nC}_{31}\right)$.

To summarise, $\delta^{2} \mathrm{H}$ values in $n$-alkanes from leaf waxes were only minimally altered up to $350{ }^{\circ} \mathrm{C}$ with an increasing trend toward ${ }^{2} \mathrm{H}$ enriched values occurring at $450{ }^{\circ} \mathrm{C}$. In contrast, in wood tissues (bark and xylem) the original unaltered $\delta^{2} \mathrm{H}$ signal was lost at 250-350 ${ }^{\circ} \mathrm{C}$. The observed variations are similar to those described for $\delta^{13} \mathrm{C}_{\text {wax }}$ [36].

\section{Discussion}

Variation in $\delta^{2} \mathrm{H}$ values between different plant organs can at least partly be explained by physiological and chemical differences which affect alkane biosynthesis and isotopic fractionation in different plant tissues [37]. Although it has been demonstrated that isotopic fractionation of plant xylem water does not occur during root uptake and transport to the leaf, thereby ensuring xylem carries the isotopic signature of the source water, significant differences in $\delta^{2} \mathrm{H}$ values have been reported between xylem sap, twigs, roots, and wood core [38]. It has also been demonstrated that hydrogen isotopic fractionation is affected by photosynthetic processes, with significant differences in $\delta^{2} \mathrm{H}$ values observed between plant photosynthetic organs and heterotrophic organs [39].

It is widely accepted that long-chain $n$-alkanes $\left(\mathrm{nC}_{27}-\mathrm{nC}_{33}\right)$, derived from epicuticular leaf waxes, represent the dominant source of $n$-alkanes in sediments [40]. However, in archaeological contexts or other anthropogenic settings we should not discount the possibility that other plant organs may represent a source of sedimentary $n$-alkanes. Well preserved charred plant tissues and fragments of microcharcoal, which are not visible at the macroscopic scale of excavation, are frequently observed in soil micromorphological samples collected from archaeological sites [14,41-43]. In occupation horizons, these materials may represent fuel residues directly linked to combustion features, or alternatively, they may have been deposited through natural agents. For instance, microcharcoal is commonly registered in palynological datasets and has been utilised to study the frequency of natural fires linked to climate shifts [44-46]. Our findings emphasise the need to carefully consider the depositional setting, particularly relating to anthropogenic combustion activities, when interpreting molecular or isotopic information from sedimentary $n$-alkanes in archaeological contexts. The unintentional incorporation of fine charred particles within sediment samples, which has been subjected to temperatures of $450^{\circ} \mathrm{C}$ or greater, could lead to misinterpretations of leaf wax $\delta^{2} \mathrm{H}$ values and molecular ratios, such as CPI and ACL, with significant implications for palaeoclimatic reconstruction. The application of complementary techniques, such as soil micromorphology, can identify charred particles' presence and help eliminate potential biases in the molecular and geochemical datasets. This approach has already effectively been demonstrated at the Middle Palaeolithic site of Abric del Pastor (Alcoy, Spain), where abrupt fluctuations in $n$-alkane distribution and compound-specific carbon and hydrogen isotope values through stratigraphic units $\mathrm{IVd}$ and IVc were interpreted as resulting from the presence of microscopic charred fuel residues in the sediment samples [47].

On the other hand, our results here demonstrate that the change in $\delta^{2} \mathrm{H}$ values in leaves was generally minimal at temperatures up to $350{ }^{\circ} \mathrm{C}$, with a maximum difference of $\sim 4$ and $\sim 7 \%$ for $\mathrm{nC}_{29}$ and $\mathrm{nC}_{31}$, respectively, ranging from -131 to $-135 \%$, and -128 to $-135 \%$. This relatively minor ${ }^{2} \mathrm{H}$ depletion is despite a dramatic decrease $(\sim 79 \%)$ in total $n$-alkane concentration within this temperature range, from 459.1 to $97 \mu \mathrm{g} / \mathrm{g}$. Although 
the effects of short-term low-temperature combustion on $n$-alkane $\delta^{2} \mathrm{H}$ values have not been widely investigated, our results are broadly consistent with studies elsewhere which observed a maximum difference of $\sim 10 \%$ in $\delta^{2} \mathrm{H}$ values of a pure $n$-alkane mixture $\left(\mathrm{nC}_{15}\right.$ to $\mathrm{n}-\mathrm{C}_{38}$ ) heated at $100-300{ }^{\circ} \mathrm{C}$ [48]. However, it is worth noting that study was based on a heating duration of $24 \mathrm{~h}$ under oxygen-free conditions. As these do not reflect real conditions in the archaeological record, and anthropogenic combustion processes are not produced in the total absence of oxygen, there is a need for more studies like ours which seek to replicate field conditions in so far as is possible.

The result from our Celtis australis leaf samples is potentially significant, as it implies that low-temperature alteration of fossil leaf waxes within sediments $\left(<350{ }^{\circ} \mathrm{C}\right)$ may not eradicate the hydrogen isotope climate signature, opening the door to high-precision onsite palaeoclimate records from lipid biomarkers recovered from archaeological combustion features. Other studies have drawn attention to the potential for thermally altered sedimentary substrates, which underly the black layer of flat combustion features, to yield archaeological information about human activity preceding the combustion event [14]. These sediments, which represent occupation surfaces on which fires were built, do not typically exceed temperatures of $350{ }^{\circ} \mathrm{C}$ and may, therefore, be suitable for compound-specific hydrogen isotope analysis. Such an approach would allow for well-dated palaeoclimate records directly associated with human activities and create a new avenue for exploring human responses to climate change at the site-specific scale. A similar approach has recently been applied elsewhere and demonstrated that $\delta^{2} \mathrm{H}$ values of lipid residues preserved in pottery from Late Neolithic levels at Çatalhöyük carried the climatic signature of the North Atlantic abrupt climate event which occurred 8.2 kya [49].

Notwithstanding the relatively small number of samples analysed here, our results provide the initial steps toward establishing boundary conditions for constraining the maximum potential alteration of fossil leaf waxes in thermally altered sediments. Our results suggest that the thermally altered combustion substrates in archaeological contexts could be targeted for hydrogen isotope analysis of individual $n$-alkanes.

\section{Materials and Methods}

Leaf and branch samples of Celtis australis were collected in July 2015 and April 2016 from the area surrounding the Middle Palaeolithic site of El Salt in Alcoy, Spain (726 m asl). All samples were rinsed with distilled water to remove potential contaminants and ovendried at $60^{\circ} \mathrm{C}$ for $24 \mathrm{~h}$ at the Archaeological Micromorphology and Biomarker Laboratory (AMBI), Universidad de La Laguna, Tenerife. Leaf ( $4 \mathrm{~g} ; 1 \mathrm{~cm}$ length) and branch $(20 \mathrm{~g} ; 2 \mathrm{~cm}$ diameter) samples were placed in ceramic crucibles $(4.2 \mathrm{~cm} \times 2.5 \mathrm{~cm})$ and covered with $\mathrm{Al}$ foil to limit the supply of $\mathrm{O}_{2}$ during the heating process. All samples were heated in a muffle furnace with a ramp rate of $26^{\circ} \mathrm{C} / \mathrm{min}$ for a duration of $1 \mathrm{~h}$ to temperatures of $150{ }^{\circ} \mathrm{C} ; 250{ }^{\circ} \mathrm{C} ; 350^{\circ} \mathrm{C} ; 450^{\circ} \mathrm{C}$. Following this, samples remained in the closed furnace to cool overnight before being homogenised into a fine powder using a pestle and mortar.

Following a single cycle in the laboratory glassware washer, all non-volumetric materials were calcined at $450{ }^{\circ} \mathrm{C}$ for a duration of $10 \mathrm{~h}$ to eliminate potential contaminants. Lipids extraction was carried out with dichloromethane/methanol (DCM:MeOH, 9:1) (10-20 mL) by ultrasonic extraction $(3 \times 30 \mathrm{~min})$ at controlled temperatures $<30{ }^{\circ} \mathrm{C}$. Samples were subsequently centrifuged $(3 \times 10 \mathrm{~min}$ at $4700 \mathrm{rpm})$ and filtered through annealed glass wool. Solid-phase column chromatography ( $2 \mathrm{~mL}$ column with glass wool, $0.1 \mathrm{~g}$ quartz sand (50-70 mesh) and $1 \mathrm{~g}$ of activated silica (70-230 mesh) was used to separate the lipid extract into fractions of differing polarity. Alkanes were eluted with $3 / 8$ dead volume (DV) $n$-hexane (DV $1.5 \mathrm{~mL}, 3 / 8$ DV $562 \mu \mathrm{L}$ ). Samples were subsequently dried under a steady stream of N2 in an Organomation evaporator, internal standard (IS) $5 \alpha$-androstane (2000 mg/L in DCM, purity $\geq 99.9 \%$, Sigma-Aldrich, Bellefonte, PA, USA), 8 mg/L was then added. The compounds were analysed by gas chromatography (GC) with a coupled mass-selective detector (GC-Agilent 7890B, MSD Agilent 5977A, Agilent Technologies, Santa Clara, CA, USA) which was equipped with a HP-5MS capillary column ((5\%-phenyl)- 
methylpolysiloxane, length: $30 \mathrm{~m}$, ID: $250 \mu \mathrm{m}$, film thickness $0.25 \mu \mathrm{m}$ ). A temperature program with an initial temperature of $70^{\circ} \mathrm{C}$ for $2 \mathrm{~min}$ and a heating rate of $12^{\circ} \mathrm{C} / \mathrm{min}$ to $140{ }^{\circ} \mathrm{C}$ and a final temperature of $320^{\circ} \mathrm{C}$ was applied with a heating rate of $3{ }^{\circ} \mathrm{C} / \mathrm{min}$ for $3 \mathrm{~min}$, and a total run time of $82.83 \mathrm{~min}$, using a Helium carrier gas $(2 \mathrm{~mL} / \mathrm{min})$. The multimode injector was held at a split ratio of 5:1 at an initial temperature of $70{ }^{\circ} \mathrm{C}$ for $0.85 \mathrm{~min}$ and heated to $300^{\circ} \mathrm{C}$ at a programmed rate of $720^{\circ} \mathrm{C} / \mathrm{min}$.

Identification of individual compounds was carried out by comparing retention times and mass spectra to those of reference compounds (mix $\mathrm{C}_{8}-\mathrm{C}_{40}$ and $5 \alpha$-androstane, Supelco) and mass spectral library databases (NIST). Quantification of concentrations was achieved using calibration curves that plot the ratio Area/AreaIs versus the reference compounds' concentration. Correlation coefficients for each sample were higher than 0.995 . Concentration is expressed here in terms of $\mu \mathrm{g}$ of individual compound per gram of dry sample $\left(\mu \mathrm{g} \mathrm{gds}^{-1}\right)$.

Compound-specific hydrogen isotope analysis was performed using a Thermo Scientific Isotope Ratio Mass Spectrometer (IRMS) Delta V Advantage. The IRMS was coupled to a GC Trace1310 through a Conflo IV interface with a temperature converter GC Isolink II, with a Trace Gold 5-MS (Thermo Fisher Scientific, Bremen, Germany) fused silica capillary column ((5\%-diphenyl)-dimethylpolysiloxane, $30 \mathrm{~m}$ length $\times 0.25 \mathrm{~mm}$ i.d., $0.25 \mu \mathrm{m}$ film thickness). A helium flow rate of $1.5 \mathrm{~mL} / \mathrm{min}$ was employed for all measurements carried out in triplicate. Data acquisition and processing were carried out using Isodat 3.0 software (Thermo Fisher Scientific, Bremen, Germany). Hydrogen $\left(\delta^{2} \mathrm{H}\right)$ isotope values are reported for $n$-alkanes $C_{29}$ and $C_{31}$. Samples were injected using a Programmed Temperature Vaporising injector (PTV) in splitless mode. Temperatures initially increased from 60 to $79^{\circ} \mathrm{C}$ (held $30 \mathrm{~s}$, rate $10^{\circ} \mathrm{C} / \mathrm{min}$ ), and then to $325^{\circ} \mathrm{C}$ (held $3 \mathrm{~min}$, rate $10^{\circ} \mathrm{C} / \mathrm{s}$ ), and finally to $350{ }^{\circ} \mathrm{C}$ (held $3 \mathrm{~min}$, rate $14{ }^{\circ} \mathrm{C} / \mathrm{s}$ ). For the GC oven, a $2 \mathrm{~min}$ isothermal period at $70^{\circ} \mathrm{C}$ increasing to $140^{\circ} \mathrm{C}$ (held $2 \mathrm{~min}$, rate $12{ }^{\circ} \mathrm{C} / \mathrm{min}$ ) was followed by an increase to $320^{\circ} \mathrm{C}$ (held $15 \mathrm{~min}$, rate $3{ }^{\circ} \mathrm{C} / \mathrm{min}$ ). The high-temperature conversion (HTC) oven was maintained at $1420^{\circ} \mathrm{C}$ for all samples. Values were normalised to the Vienna Standard Mean Ocean Water (VSMOW) scale using an $n$-alkane Schimmelmann type A6 mixture ( $\mathrm{nC}_{16}$ to $\mathrm{nC}_{31}$ ) of known isotopic composition (Arndt Schimmelmann; Biogeochemical Laboratories, Indiana University). Reproducibility greater than $\pm 5.0 \%$ was attained for most samples, where reproducibility was less than $\pm 5.0 \%$, this is clearly stated.

\section{Conclusions}

Here we investigated the hydrogen isotope composition of thermally unaltered and charred Celtis australis leaves, xylem, and bark during short-term combustions ( $1 \mathrm{~h}$ ) under limited oxygen conditions in a laboratory-controlled setting, at temperatures up to $450{ }^{\circ} \mathrm{C}$. Our results demonstrate that although significant variation is $\delta^{2} \mathrm{H}_{\text {wax }}$ is observed in the xylem and bark samples, fluctuations in $\delta^{2} \mathrm{H}_{\mathrm{wax}}$ of leaf samples are generally minimal up to $350{ }^{\circ} \mathrm{C}$, however, at temperatures exceeding this, considerable changes in hydrogen isotopic composition occur. Our results sound a cautionary note on the application of $\delta^{2} \mathrm{H}_{\text {wax }}$ as a palaeoclimate proxy in archaeological contexts where the depositional environment is not well understood. We propose that this proxy be enhanced by a detailed characterisation of soil microstratigraphy, which can help eliminate potential biases that arise due to the mixing of charred microscopic particles $\left(\geq 450^{\circ} \mathrm{C}\right)$ in sediment samples. Nevertheless, our observations highlight the potential for $\delta^{2} \mathrm{H}_{\text {wax }}$ to record and retain palaeoclimate information at temperatures $\leq 350^{\circ} \mathrm{C}$ and could be employed to target thermally altered archaeological combustion substrates and link climatic and archaeological datasets at a high spatial and temporal resolution.

Author Contributions: Conceptualization, R.C. and C.M.; methodology, R.C., M.J.-E. and A.V.H.-H.; validation, R.C., M.J.-E. and A.V.H.-H.; formal analysis, R.C., M.J.-E. and A.V.H.-H.; resources, C.M.; writing—original draft preparation, R.C.; writing—review and editing, R.C., M.J.-E. and A.V.H.-H.; supervision, C.M.; project administration, C.M.; funding acquisition, C.M. All authors have read and agreed to the published version of the manuscript. 
Funding: This research was supported by the European Research Council (ERC) Consolidator Grant project PALEOCHAR-648871.

Institutional Review Board Statement: Not applicable.

Informed Consent Statement: Not applicable.

Data Availability Statement: Data is contained within the article.

Acknowledgments: The authors wish to extend thanks to C. Hernández, J. Machado and P. VidalMatutano for their support during fieldwork.

Conflicts of Interest: The authors declare no conflict of interest.

Samples Availability: Samples are not available from the authors.

\section{References}

1. Brittingham, A.; Petrosyan, Z.; Hepburn, J.C.; Richards, M.P.; Hren, M.T.; Hartman, G. Influence of the North Atlantic Oscillation on $\delta \mathrm{D}$ and $\delta 18 \mathrm{O}$ in meteoric water in the Armenian Highland. J. Hydrol. 2019, 575, 513-522. [CrossRef]

2. Diefendorf, A.F.; Mueller, K.E.; Wing, S.L.; Koch, P.L.; Freeman, K.H. Global patterns in leaf 13C discrimination and implications for studies of past and future climate. Proc. Natl. Acad. Sci. USA 2010, 107, 5738-5743. [CrossRef]

3. Glauberman, P.; Gasparyan, B.; Sherriff, J.; Wilkinson, K.; Li, B.; Knul, M.; Brittingham, A.; Hren, M.T.; Arakelyan, D.; Nahapetyan, S.; et al. Barozh 12: Formation processes of a late Middle Paleolithic open-air site in western Armenia. Quat. Sci. Rev. 2020, 236, 106276. [CrossRef]

4. Magill, C.R.; Ashley, G.M.; Domínguez-Rodrigo, M.; Freeman, K.H. Dietary options and behavior suggested by plant biomarker evidence in an early human habitat. Proc. Natl. Acad. Sci. USA 2016, 113, 2874-2879. [CrossRef]

5. Gamarra, B.; Sachse, D.; Kahmen, A. Effects of leaf water evaporative 2 H-enrichment and biosynthetic fractionation on leaf wax n-alkane $\delta 2 \mathrm{H}$ values in C3 and C4 grasses. Plant Cell Environ. 2016, 39, 2390-2403. [CrossRef]

6. Liu, J.; An, Z. A hierarchical framework for disentangling different controls on leaf wax $\delta \mathrm{D}$ n-alkane values in terrestrial higher plants. Quat. Sci. Rev. 2018, 201, 409-417. [CrossRef]

7. Niedermeyer, E.M.; Forrest, M.; Beckmann, B.; Sessions, A.L.; Mulch, A.; Schefuß, E. The stable hydrogen isotopic composition of sedimentary plant waxes as quantitative proxy for rainfall in the West African Sahel. Geochim. Cosmochim. Acta 2016, 184, 55-70. [CrossRef]

8. Sachse, D.; Billault, I.; Bowen, G.J.; Chikaraishi, Y.; Dawson, T.E.; Feakins, S.J.; Freeman, K.H.; Magill, C.R.; McInerney, F.A.; Van Der Meer, M.T.; et al. Molecular Paleohydrology: Interpreting the Hydrogen-Isotopic Composition of Lipid Biomarkers from Photosynthesizing Organisms. Annu. Rev. Earth Planet. Sci. 2012, 40, 221-249. [CrossRef]

9. Butler, D.H.; Koivisto, S.; Brumfeld, V.; Shahack-Gross, R. Early Evidence for Northern Salmonid Fisheries Discovered using Novel Mineral Proxies. Sci. Rep. 2019, 9, 147. [CrossRef] [PubMed]

10. Peris, J.F.; González, V.B.; Blasco, R.; Cuartero, F.; Fluck, H.; Sañudo, P.; Verdasco, C. The earliest evidence of hearths in Southern Europe: The case of Bolomor Cave (Valencia, Spain). Quat. Int. 2012, 247, 267-277. [CrossRef]

11. Haaland, M.M.; Friesem, D.E.; Miller, C.E.; Henshilwood, C.S. Heat-induced alteration of glauconitic minerals in the Middle Stone Age levels of Blombos Cave, South Africa: Implications for evaluating site structure and burning events. J. Archaeol. Sci. 2017, 86, 81-100. [CrossRef]

12. Urban, T.M.; Rasic, J.T.; Alix, C.; Anderson, D.D.; Chisholm, L.; Jacob, R.W.; Manning, S.W.; Mason, O.K.; Tremayne, A.H.; Vinson, D. Magnetic detection of archaeological hearths in Alaska: A tool for investigating the full span of human presence at the gateway to North America. Quat. Sci. Rev. 2019, 211, 73-92. [CrossRef]

13. Whitau, R.; Vannieuwenhuyse, D.; Dotte-Sarout, E.; Balme, J.; O'Connor, S. Home Is Where the Hearth Is: Anthracological and Microstratigraphic Analyses of Pleistocene and Holocene Combustion Features, Riwi Cave (Kimberley, Western Australia). J. Archaeol. Method Theory 2018, 25, 739-776. [CrossRef] [PubMed]

14. Mallol, C.; Hernández, C.M.; Cabanes, D.; Sistiaga, A.; Machado, J.; Rodríguez, Á.; Pérez, L.; Galván, B. The black layer of Middle Palaeolithic combustion structures. Interpretation and archaeostratigraphic implications. J. Archaeol. Sci. 2013, 40, $2515-2537$. [CrossRef]

15. March, R.J.; Lucquin, A.; Joly, D.; Ferreri, J.C.; Muhieddine, M. Processes of Formation and Alteration of Archaeological Fire Structures: Complexity Viewed in the Light of Experimental Approaches. J. Archaeol. Method Theory 2014, 21, 1-45. [CrossRef]

16. Aldeias, V. Experimental Approaches to Archaeological Fire Features and Their Behavioral Relevance. Curr. Anthropol. 2017, 58, 191-205. [CrossRef]

17. Leierer, L.; Alonso, Á.C.; Pérez, L.; Lagunilla, Á.H.; Herrera-Herrera, A.V.; Connolly, R.; Jambrina-Enríquez, M.; Gómez, C.M.H.; Galván, B.; Mallol, C. It's getting hot in here-Microcontextual study of a potential pit hearth at the Middle Paleolithic site of El Salt, Spain. J. Archaeol. Sci. 2020, 123, 105237. [CrossRef]

18. Braadbaart, F.; Poole, I. Morphological, chemical and physical changes during charcoalification of wood and its relevance to archaeological contexts. J. Archaeol. Sci. 2008, 35, 2434-2445. [CrossRef] 
19. Ntinou, M.; Tsartsidou, G. Domestic and ritual use of plants and fuels in the neolithic cave of Alepotrypa, southern Peloponnese, Greece: The wood charcoal and phytolith evidence. Quat. Int. 2017, 457, 211-227. [CrossRef]

20. Vidal-Matutano, P. Firewood and hearths: Middle Palaeolithic woody taxa distribution from El Salt, stratigraphic unit Xb (Eastern Iberia). Quat. Int. 2017, 457, 74-84. [CrossRef]

21. Vidal-Matutano, P.; Pérez-Jordà, G.; Hernández, C.M.; Galván, B. Macrobotanical evidence (wood charcoal and seeds) from the Middle Palaeolithic site of El Salt, Eastern Iberia: Palaeoenvironmental data and plant resources catchment areas. J. Archaeol. Sci. Rep. 2018, 19, 454-464. [CrossRef]

22. Albert, R.M.; Cabanes, D. Fire in prehistory: An experimental approach to combustion processes and phytolith remains. Isr. J. Earth Sci. 2007, 56, 175-189. [CrossRef]

23. Allué, E.; Cabanes, D.; Solé, A.; Sala, R. Hearth Functioning and Forest Resource Exploitation Based on the Archeobotanical Assemblage from Level J. In High Resolution Archaeology and Neanderthal Behavior; Roura, E.C.I., Ed.; Springer: Dordrecht, The Netherlands, 2012; pp. 373-385.

24. Devos, Y.; Hodson, M.J.; Vrydaghs, L. Auto-Fluorescent Phytoliths: A New Method for Detecting Heating and Fire. Environ. Archaeol. 2020. [CrossRef]

25. Rodríguez-Cintas, Á.; Cabanes, D. Phytolith and FTIR studies applied to combustion structures: The case of the Middle Paleolithic site of El Salt (Alcoy, Alicante). Quat. Int. 2017, 431, 16-26. [CrossRef]

26. Cliquet, D.; Dumont, J.L.; Dupont, J.P.; Fosse, G.; Jouis, M.; Lanoe, B.; Marite, C.; Morel, J.; Quillard, J.; Thiebault, S.; et al. Approche d'une Etude Comparative des Matières Organiques de Foyers Préhistoriques et de Foyers Expérimentaux: L'exemple du Gisement Moustérien de Saint-Germain-des-Vaux (Manche); Association pour la Promotion de la Recherche Archéologique en Ile de France: Nemours, Seine-et-Marne, France, 1989.

27. March, R.J.; Baldessari, A.; Gross, E.G. Determinación de compuestos orgánicos en estructuras de combustión arqueológicas. In Nature et Funtion des Foyes Préhistoriques Actes du Colloque International de Nemours Mémoires du Musée du Préhistoire D'Ile de France; Olive, M., Taborin, Y., Eds.; Association pour la Promotion de la Recherche Archéologique en Ile de France: Nemours, Seine-et-Marne, France, 1989; pp. 47-58.

28. Rottlander, R.C.A. Chemische untersuchungen an sedimenten der Höhle Geissenklösterle bei Blaubeuren. Fundber. Aus BadenWürttemberg 1989, 14, 23-32.

29. Buonasera, T.; Herrera-Herrera, A.V.; Mallol, C. Experimentally Derived Sedimentary, Molecular, and Isotopic Characteristics of Bone-Fueled Hearths. J. Archaeol. Method Theory 2019, 26, 1327-1375. [CrossRef]

30. Choy, K.; Potter, B.A.; McKinney, H.J.; Reuther, J.D.; Wang, S.W.; Wooller, M.J. Chemical profiling of ancient hearths reveals recurrent salmon use in Ice Age Beringia. Proc. Natl. Acad. Sci. USA 2016, 113, 9757-9762. [CrossRef]

31. Jambrina-Enríquez, M.; Herrera-Herrera, A.V.; Rodríguez de Vera, C.; Leierer, L.; Connolly, R.; Mallol, C. n-Alkyl nitriles and compound-specific carbon isotope analysis of lipid combustion residues from Neanderthal and experimental hearths: Identifying sources of organic compounds and combustion temperatures. Quat. Sci. Rev. 2019, 222, 105899. [CrossRef]

32. Lejay, M.; Alexis, M.; Quénéa, K.; Sellami, F.; Bon, F. Organic signatures of fireplaces: Experimental references for archaeological interpretations. Org. Geochem. 2016, 99, 67-77. [CrossRef]

33. March, R.J. Searching for the Functions of Fire Structures in Eynan (Mallaha) and Their Formation Processes: A Geochemical Approach. In Natufian Foragers in the Levant: Terminal Pleistocene Social Changes in Western Asia; Archaeological, Series; Bar-Yosef, O., Valla, F.R., Eds.; International Monographs in Prehistory: Ann Arbor, MI, USA, 2013; pp. 227-283.

34. Bray, E.E.; Evans, E.D. Distribution of $\mathrm{n}$-paraffins as a clue to recognition of source beds. Geochim. Cosmochim. Acta 1961, $22,2-15$. [CrossRef]

35. Freeman, K.H.; Pancost, R.D. Biomarkers for Terrestrial Plants and Climate. Treatise on Geochemistry, 2nd ed.; Elsevier: Amsterdam, The Netherlands, 2014; pp. 395-416.

36. Jambrina-Enríquez, M.; Herrera-Herrera, A.V.; Mallol, C. Wax lipids in fresh and charred anatomical parts of the Celtis australis tree: Insights on paleofire interpretation. Org. Geochem. 2018, 122, 147-160. [CrossRef]

37. Post-Beittenmiller, D. Biochemistry and Molecular Biology of Wax Production in Plants. Annu. Rev. Plant Physiol. Plant Mol. Biol. 1996, 47, 405-430. [CrossRef] [PubMed]

38. Zhao, L.; Wang, L.; Cernusak, L.A.; Liu, X.; Xiao, H.; Zhou, M.; Zhang, S. Significant Difference in Hydrogen Isotope Composition Between Xylem and Tissue Water in Populus Euphratica. Plant Cell Environ. 2016, 39, 1848-1857. [CrossRef]

39. Sanchez-Bragado, R.; Serret, M.D.; Marimon, R.M.; Bort, J.; Araus, J.L. The Hydrogen Isotope Composition $\delta 2 \mathrm{H}$ Reflects Plant Performance. Plant Physiol. 2019, 180, 793-812. [CrossRef] [PubMed]

40. Eglinton, G.; Hamilton, R.J. Leaf epicuticular waxes. Science 1967, 156, 1322-1335. [CrossRef] [PubMed]

41. Friesem, D.E.; Zaidner, Y.; Shahack-Gross, R. Formation processes and combustion features at the lower layers of the Middle Palaeolithic open-air site of Nesher Ramla, Israel. Quat. Int. 2014, 331, 128-138. [CrossRef]

42. Goldberg, P.; Miller, C.E.; Schiegl, S.; Ligouis, B.; Berna, F.; Conard, N.J.; Wadley, L. Bedding, hearths, and site maintenance in the Middle Stone Age of Sibudu Cave, KwaZulu-Natal, South Africa. Archaeol. Anthropol. Sci. 2009, 1, 95-122. [CrossRef]

43. Leierer, L.; Jambrina-Enríquez, M.; Herrera-Herrera, A.V.; Connolly, R.; Hernández, C.M.; Galván, B.; Mallol, C. Insights into the timing, intensity and natural setting of Neanderthal occupation from the geoarchaeological study of combustion structures: A micromorphological and biomarker investigation of El Salt, unit Xb, Alcoy, Spain. PLoS ONE 2019, 14, e0214955. [CrossRef] 
44. Clark, J.S. Particle motion and the theory of charcoal analysis: Source area, transport, deposition, and sampling. Quat Res. 1988, 30, 67-80. [CrossRef]

45. Swain, A.M. A history of fire and vegetation in northeastern Minnesota as recorded in lake sediments. Quat. Res. 1973, 3, 383-396. [CrossRef]

46. Val-Peón, C.; Expósito, I.; Soto, M.; Burjachs, F. A taphonomic approach to the pollen assemblage from layer M of the Abric Romaní archaeological site (NE Iberian Peninsula). Rev. Palaeobot. Palynol. 2019, 270, 19-39. [CrossRef]

47. Connolly, R.; Jambrina-Enríquez, M.; Herrera-Herrera, A.V.; Vidal-Matutano, P.; Fagoaga, A.; Marquina-Blasco, R.; Marin-Monfort, M.D.; Ruiz-Sánchez, F.J.; Laplana, C.; Bailon, S.; et al. A multiproxy record of palaeoenvironmental conditions at the Middle Palaeolithic site of Abric del Pastor (Eastern Iberia). Quat. Sci. Rev. 2019, 225, 106023. [CrossRef]

48. Wang, C.; Eley, Y.; Oakes, A.; Hren, M. Hydrogen isotope and molecular alteration of n-alkanes during heating in open and closed systems. Org. Geochem. 2017, 112, 47-58. [CrossRef]

49. Roffet-Salque, M.; Marciniak, A.; Valdes, P.J.; Pawłowska, K.; Pyzel, J.; Czerniak, L.; Krüger, M.; Roberts, C.N.; Pitter, S.; Evershed, R.P. Evidence for the impact of the 8.2-kyBP climate event on Near Eastern early farmers. Proc. Natl. Acad. Sci. USA 2018, 115, 8705-8709. [CrossRef] [PubMed] 